many cases the only final cause of loss of motion is due to this state of the joints. Of all the agencies which impede movement it is the most difficult to relieve. Were we asked to state in what essential respect these lesions differ from subacute rheumatic disease of the sam paris, we shuuld certainly.be at some luss to discern a difference." 2

In a subsequent work ${ }^{3}$ Dr. Weir Mitchell again refers to the curious arthritic changes which may follow dislocations, ball wounds, contusions, or even compression of the nerves.

"We may have one articulation-and if only one a large oneinvolved, or perbaps all the joints of a finger, or every joint in the involved, or perhaps all the joints of a finger, or every joint in the hand, or of the entire limb may suffer. The swelling is never very great, the redness usually sligut, and the tenderness on touch or thotion exquisite. ...... It is quite clear that injuries of the spine, diseases of unis organ or the brain. and wounds, or unp form of lesion of nerves are capable of develuping in the jointe infiammatory condiarthritis in their symptoms and results that no clinical skill can

In my secend Croonian lecture, published in THE LANOET (vol. i., 1886, p. 673), I quoted very freely from Dr. Mitchell's works, showing how subacute inflammation of the joints may be brought about by nerve lesions. Reference is also made there to two cases recorded by Sir William Gull, in which lesions of the cord were "attended with an affection of the joints not to be readily distinguished from that which occurs in acute rheumatism," and I directed special attention to Sir William Gull's very suggestive remarks upon these cases. The views of scott Alison, Brown-Séquard, ${ }^{6}$ and Oharcot ${ }^{7}$ upon the nutritive disorders in the articulations consecutive on lesions of the nervous centres were also dealt with. Brown-Séquard's view regarding the arthritis of paralytic patients and the painful sensations in the muscles associated therewith was that they were due to a subacute inflammation in the painful limbs, "the result of an irritation of the vaso-motor or nutrition nerves of the encephalon." According to recent investigations, however -

Pathological facts appear to show that the trophic nerves of the bones and joints are found in the mixed nerve trunk and that they issue along with the motor fibres from the anterior cornua of the spinal cord, where they are, like the muscular trophic fibres, connected with cord, where they are, like the muscular trophic fibres, connected with a group of large caudate cells," and "it seems now generally armitted that both irritatire and destroying lesions of the ganglion cells of the oblongata, pons, and crura. or of the efferent fibres which nnite these chlongata, pons, and crura. or of the efferent fibres which inite these cells with the periphery, may give rise to active atrophy of muscle." ganglion cells of the anterior horns exercise a controlling influence ganglion cells of the anterior horns exercise a controlling influence upon the nutrition of the bones and joints, while those of the posterior

horns stind in

It is not unreasonable, therefore, to assume that the arthritic changes following upon gunshot wounds or other injuries of the nerves, as well as the arthritic changes in rhenmatoid arthritis, are due to, or associated with, changes in the spinal cord, commencing with congestion or myelitis and chiefly affecting the ganglion cells of the anterior horns. ${ }^{10}$ If this be the case the natural influence would be that the treatment should be directed to the abatement.of this condition, which probably can be done most effectively by cupping or blistering the spine, and more particularly the parts in the neighbourhood of the cervical or lumbar enlargements from which the affected nerves emerge, and by maintaining the counter-irritation for some ten days or a fortnight at a time.

Dr. Weir Mitchell, Dr. Moorbouse, and Dr. Keen, after exhausting their ingenuity in devices for the relief of the intractable causalgia associated sometimes with nerve wounds obtained the best results by thorough and repeated blistering of the spine-a method of treatment for arthritic troubles which was first suggester by Dr. Weir Mitchell's father, Dr. J. K. Mitchell, ${ }^{11}$ in 1831 . He reports some cases of a striking character in which arthritic symptoms supervened upon injury to the spinal cord. These cases were successfully treated by applying cupping glasses to the spine, abstracting from 8 to 16 ounces of blood from the neighbourhood of the cervical or lumbar enlargements,

2 Loc. cit., p 83

3 On Injuries to Nerves, Philadelphia and Lnndon, 1872. p. 168.

Guy's Hospital Reports, third series, vol. iv.. 1858, Cases 27 and 28.

5 Arthritis Occurring in the Course of Paralysis. THF Lances, 1846, ol. 11., p. 278.

Society, 1877, p. 92 .

Society, 1877, p. 92.

Ross : Diseases of the Nervous System, seco

9 Loc. cit., p. 825 .
10 In Brain, vol. $x \times v$ (1902), p. 418 , a case (No. 4) of great interest is reported hy Dr.F. W. Mott. F.R.S., and Mr. A F. Tredyold of chronic rheumatold arthritis, giving an excellent ancount of the changes in the spinal cord, as exhibited on mierosenpical examination.

11 On a New Practice in Acute and Chronic Rheumatism. By J. K. Mitchell, M D. American Journal of the Medical Sciences, 1831,
vol. vili., p. 55 . according as the upper or lower extremities were affected, and, if the cupping did not afford relief, applying blisters to the same regions.

As regards the treatment of rheumatoid arthritis, I have obtained more satisfactory results by the use of counterirritation than by any other method.

May I add, in conclusion, that it is of the utmost importance when recourse is had to counter-irritation or cupping, that it should be applied to the right spot namely, the neighbourhood of the cervical or lumbar enlargement, according as the upper or lower extremities are affected; applied to the dorsal region, for example, it is much less efficacious ; and if blisters are applied they should be of fair size-one of four to six inches in length by two inches in breadth, on each side of the spine, and the blistered surface shonld be dressed daily with savine ointment for a week or 10 days-the counter-irritation being thorough and prolonged. In some cases this treatment, especially in the early stage, may be advantageously combined with the use of opinm to relieve the pain. Full details, however, of this mode of treatment will be found in an article of mine in Latham and Fnglish's System of Treatment, vol. i., pp. 405-7.

May 17th, 19:8.

I am, Sir, yours faithfully, P. W. LATHAM

\section{THE CAUSATION OF MYOPIA.}

To the Editor of THE LANCET.

SIR, - In reference to the annotation in your issue of May 11th on this subject a point which should be emphasised, and which my experience here daily confirms, is that whatever be the foundation canse of myopia there is a danger in attention being directed to one side only of the predisposing factors involved, and a side which I think is not the vital one. I believe that the essential factor in the prevention of myopia is the attainment of good health and sound physique by all the means possible-healthy housing, fresh air, good food, exercise, and avoidance of the various infections common to early life; and I would like here again to put the question whether myopia is not more probably due to some chronic toxic absorption which interferes with the proper development of the sclerotic.

Last week I examined 300 agricultural labourers, and found only one case of axial myopia above one dioptre. I have in the last three days seen a corresponding number of miners, labourers, \&c., and found 18 cases of axial myopia above one dioptre. The predisposing factors in school surroundings which are supposed to be so important are common to both in this part of the country.

I am, Sir, yours faithfully,

J. KIRK, M.D.

Oculist to Edinburgh National Service Boards.

Edinburgh, May 16th, 1918.

\section{THE PREDISPOSITION TO CANCER OF THE TONGUE.}

To the Editor of THE LANCET.

Sin,-I am interested in the subject of cancer of the tongue, and am anxious to ascertain whether there is a family predisposition to the disease such as occurs in some other forms of cancer.

Will any of your readers kindly tell me whether they know at first hand of $(a)$ cancer of the tongne occuring in more than one member of the same generation of a family; (b) in successive generations of the same family-i.e., father and son; (c) whether in the rarer case of lingual cancer in women the disease has occurred in families with a markedly cancerous history ? I am, Sir, yours faithfully,

10^, Chandos-street, W., May 25th, 1918. D'ARCy Power.

The ParLIamentary Representation OF The CoMbined UNIVERsities.-Mr. Herbert G. Williams, hon. secretary to the Combined Universities Conservative and Unionist Association, writing from 120, Ashley-gardens, London, S.W.1, urges graduates of the Universities of Durbam, Manchester, Liverpool, Leeds, Sheffield, Birmingham, and Bristol, to write to the registrars of their respective Universities for the forms of application for registration as electors. The relatives of those gradantes who are serving in the Army or Navy can obtain the forms of application in order to forward them, and all graduates serving overseas will be able to vote, either by post or by proxy. Mr. Williams will send further particalars relating to the University franchise to any applicant. 